
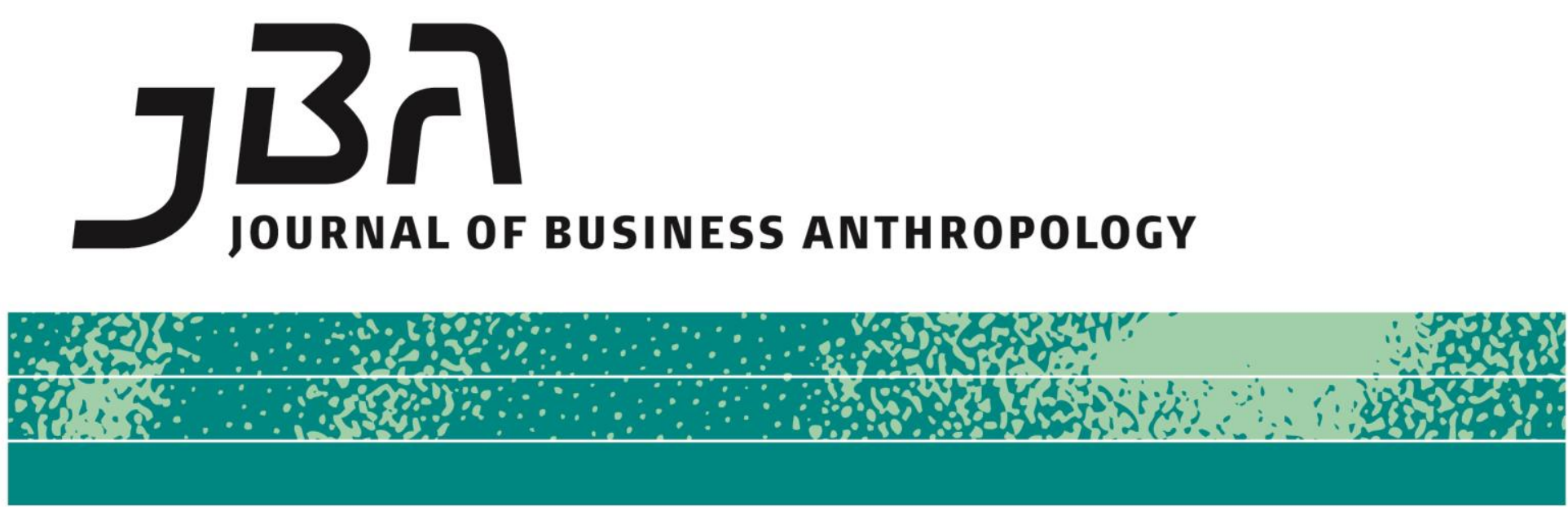

\title{
The Consequences of Culture in International Business: A Long Overdue Commentary
}

Nigel Holden

It has been observed that "culture"-note the inverted commas-"is said to be one of the two or three most complex words in the English language" (Eagleton, 2000: 1). Despite Raymond Williams' admonishment-"culture is ordinary" (Williams, 1958; see also Williams 1976, 1981)-over the years the general international business (IB) literature has been awash with definitions of this troublesome term. The dominant one in the general management literature is that of the

Page 1 of 11

JBA 3(2): 180-190 Fall 2014

(C) The Author(s) 2014 ISSN 2245-4217

www.cbs.dk/jba Dutch scholar, Geert Hofstede, which by now must be as famous for its lasting power as for its content. In this contribution I am going to overwhelmingly confine the discussion about the influence of Hofstede to the academic discipline of cross-cultural management, which we might term the specialist sub-division of IB for leading-let us hope-the latest thinking about culture in the context of international business endeavour. ${ }^{1}$

\section{Culture and the future evolution of the MNC}

The branch of management studies known as cross-cultural

\footnotetext{
${ }^{1}$ My thanks are due to Dr Mitch Sedgwick for valuable comments on earlier versions of this essay.
} 
management is a relatively young field of education and research. It was originally a form of comparative management, which took its brief to be "comparison of managerial behaviour and other aspects of management in different countries" (Weinshall, 1975: 7). We can trace its beginnings to the late 1950s, when it was largely preoccupied with one dominant issue: the cultural challenges associated with the management and-this is important-the future evolution of the multinational corporation MNC). This perspective was predicated on the conviction that the MNC-that is to say, the American MNC-was "taking over the basic roles hitherto traditionally regarded as the province of the nation states" (Weinshall, 1975: 404). Beacons of a new, more optimistic, convergence-led era in human affairs, the MNCs:

- Constituted barriers to war;

- Moved technology, capital and know-how and more advanced standards of living from the developed to the developing areas of the world, helping bridge existing economic gaps;

- Carried with them the most advanced managerial concepts and techniques

- "Induced less advanced nation states, through their mere presence, to change their cultural environments" (Weinshall, 1975: 404; added emphasis).

It was recognised that "the diversity of cultural values, beliefs, habits and traditions exerts profound influence on managerial relations" (Webber, 1970; in Weinshall, 1975: 53; note 1), and therefore that managerial know-how honed for domestic business operations (i.e. in the USA) needed significant readjustment for running internationally operating organisations. At the time we are talking about-some forty or fifty years ago-the theoretical and conceptual tools were not available, though many leading scholars were acutely aware of this serious deficiency. So it was that "a vast amount of work needs to be in the cultural sphere of international business management" (Richman, 1965; ibid.: 36). Nor did anthropology, the traditional branch of scholarship dealing with culture and communities, seem offer much help (Weinshall, 1975). The idea of insights from "ancient, savage, exotic, and extinct peoples" (Carson, 1967; ibid.: 239) did not seem applicable to the complex structures of industrial society. Besides, most anthropologists did not regard business organisations as worthy of their time and resources (Weinshall, 1975). Yet, there was no other social science which had more to say about culture than anthropology. The seeming failure of anthropology at the time to grasp that it had a good deal to offer management studies has weakened its relevance in that domain ever since; certainly to management scholars, and quite possibly to anthropologists as well. .

In 1971, a survey of 526 studies of organizational behaviour concluded that research relating to cross-cultural issues was "a morass" 
(Roberts, 1975: 59); that "the search for differences in traits among cultures is futile as an explanatory device" (ibid.: 62); and that "the lack of systemization in instrumentation is possibly the best indicator of how unscientific the area [cross-cultural research] actually is" (ibid.: 92). Most incisively, it was noted: "without some theoretical notions explaining culture and predicting its effects on other variables, we cannot make sense of cross-cultural comparisons. The problem is to explain the effects of culture on behaviour, not to make inferences about behaviour in spite of culture, (ibid.: 63).

By the early 1980s it was noted, in a survey of 11,219 articles published in leading management journals between 1971 and 1980, that less than five per cent focused on cross-cultural issues. The author, Nancy Adler, who would become one of the world's leading professors in the field of culture and international management, observed that "internationalisation demands that a narrow domestic paradigm be replaced with one that can encompass the diversity of a global perspective" (Adler, 1983).

A few years later Adler provided the first comprehensive definition of cross-cultural management. According to her:

"Cross-cultural management studies the behaviour of people in organizations around the world and trains people to work in organizations with employee and client populations from several cultures. It describes organizational behaviour within countries and cultures; compares organizational behaviour across countries and cultures; and perhaps, most importantly, seeks to understand and improve the interaction of co-workers, clients, suppliers, and alliance partner from different cultures and countries and cultures. Cross-cultural management thus expands the scope of domestic management to encompass the international and multicultural spheres" (Adler, 1986: 10; original emphasis).

\section{Hall, Hofstede and Hermes}

In the meantime two major new ways of explaining culture in international business entered the public domain. In 1959 American anthropologist, Edward T Hall, published his book The silent language, in which he introduced the relativistic terms "high context" and "low context" as key differentiators of cultural groups. So-called "highcontext cultures" are those in which messages among the groups concerned are implicitly understood and in which there is a strong emphasis on interpersonal relationships. In today's world, a very high proportion of high-context cultures are what are termed "emerging markets" (see: Gammeltoft et al, 2012; Kearney, 2012), which demographically-speaking constitute the absolute majority of the population of the planet. By contrast, "low-context cultures," of which 
the US is the standard exemplar, are those in which more information is explicitly coded into spoken language and in which the style of interpersonal communication is direct.

Hall's scheme is not one of absolutes and he made no attempt to calibrate differences between cultures. It is easy to dismiss his contribution as naïve. He was certainly eclipsed by Hofstede, to whom we turn in a moment. Yet Hall did two notable things. First, he stressed the importance of context and, second, he saw context as a cradle of communication. In his words: "context is the information that surrounds an event: it is inextricably bound up with the meaning of the event. In a high-context society, the context of communication can be equally important as the event" (Hall, 1990:6). Interestingly, the matter of context is gaining in stature in IB writing today (Michailova, 2011)

Then, in 1980, a landmark book called Culture's Consequences, written by the Dutch organisational psychologist, Geert Hofstede, was published. From 1968 to 1972 Hofstede had gathered data on some 100,000 employees of IBM (code-named Hermes in his writings) in 40 countries, and analysed them to establish cross-culturally relevant disparities in their work values (Hofstede, 1980). For the first time, and on a scale never matched since, Hofstede indexed and modelled cultural differences, creating his famous cultural dimensions. Initially he advanced four:

- Power distance: the degree of inequality that members of a given culture accept or expect;

- Uncertainty avoidance: the extent to which members of a given culture accommodate uncertainty and change;

- Individualism/collectivism: the degree to which members of a given culture show "a preference for a loosely-knit social framework in which individuals are expected to take care of only themselves and their immediate families or its opposite, collectivism, represents a preference for a tightly-knit framework in society in which individuals can expect their relatives or members of a particular in-group to look after them in exchange for unquestioning loyalty;" ${ }^{2}$

- Masculinity/femininity: the degree to which a given culture emphasises so-called masculine values, such as competitiveness or striving for recognition, or so-called feminine ones, such as cooperativeness and concern for relationships.

In his later work Hofstede added a fifth dimension, long-term orientation, which refers to a given culture's time horizon. Thanks to his dimensions, Hofstede in effect systematized the notion of cultural distance as referring to "national/societal values on which nations or societies tend to differ" (Tung and Verbeke, 2010). Whilst, as we shall

${ }^{2}$ Source: http://geert-hofstede.com/dimensions.html 
see, Hofstede's work has been subjected to increasing scholarly criticism, his contribution ranks as an outstanding intellectual achievement.

Culture's Consequences was to become the holy writ of crosscultural management studies. Hofstede's definition of culture as "the mental programming of the mind that distinguishes one human group from another" (Hofstede, 1980: 21) is arguably the most cited one across the entire gamut of management studies. Although the Hofstede data were concerned with the work values of employees in a giant American corporation, they were quickly deemed to represent much bigger human collectivities, namely nation states. So powerful was the Hofstede study that, ever since, "a distinctive feature [of the crosscultural management literature] has been the proliferation of values and measurement" (Tsui et al., 2007).

\section{Values under fire}

Throughout these epochal transformations, though Hofstede's dimensions remained dominant, there are two other major, and related, approaches that have made an impact. Both are values-based. First is the contribution of Shalom Schwartz, first published in 1992 and based on the concept of value types. He identifies ten: power, achievement, hedonism, stimulation, self-direction, universalism, benevolence, tradition, conformity and security. He then identifies bipolar value dimensions: self-transcendence and self-enhancement, conservatism and openness to change, hierarchy and egalitarianism, embeddedness and autonomy, mastery and harmony. He also maps the locations of countries associated with particular dimensions-thus, like Hofstede, contributing to attempts to capture cultural distance in a multidimensional way.

The second scheme is associated with Project GLOBE (Global leadership and organizational effectiveness.), a multinational research collaboration (House et al., 2004) The authors behind Project GLOBE premised their work on the three key assumptions:

- Societal cultural values and practices affect the behaviour of organisational actors;

- Societal cultural values and practices affect in turn organisational culture and behaviour;

- Cultural forces affect relationships.

Project GLOBE has been criticised for being in a fundamental sense similar to the Hofstede scheme. It identifies nine dimensions, five of which are similar to those proposed by Hofstede. Inevitably, as a result, Project GLOBE has been seen to be a variant of Hofstede model (French, 2010; Hofstede, 2006; Tung and Verbeke, 2010). This is rejected by the GLOBE protagonists who claim that their dimensions "reflect the 
dimensions of Hofstede's theory but also David McClelland's theory of national economic development ....and human motivation ... We believe that the nine core GLOBE dimensions reflect important aspects of the human condition" (House et al., 1999: 16).

In a very thorough examination of CCM research, Tsui and his coauthors noted that, although values are central to any appreciation of cross-cultural management in theory and practice as presently conceived, the "the abundance of culture dimensions"-not just Hofstede's, of course-"and corresponding measures [do] not necessarily advance our knowledge on culture" (Tsui et al, 2007). As Primecz and his co-authors have noted, value surveys may be "a compelling means of investigation, yet they cannot tell us how people actually enact [their] values in, for example, an intercultural interaction" (Primecz et al., 2011: 3). This highlights a serious deficiency in CCM studies.

\section{Hofstede under attack}

In the last few years, Hofstede's contribution in particular has come under increasing attack with "a growing body of criticism highlighting the limitation of his paradigm which ranges from an identification of perceived anomalies in his data to the fundamental questioning of the models' explanatory usefulness and efficacy" (French, 2010: 57). In a recent rebuff, for example, Ybema and Nyíri, (2015, forthcoming) have been damning, vividly contending that "the Hofstedean approach casts individual actors in the role of puppets who dance to the pulling of their national culture's strings." Although it has been argued that the work environment described by Hofstede belongs to a by-gone corporate era (Holden, 2002), "there is no apparent waning of interest in Hofstede's research. Instead, we find continuing evidence of the durability of his work" (French, 2010: 57).

Be that as it may, there is "a deep division among cross-cultural researchers as to what constitutes culture (that is, its key dimensions), how culture should be measured, and what culture implies for managerial practice. This debate is important because, unless researchers pay attention to these issues and differing opinions, many will and often do adopt a particular approach to defining cultural dimensions and measuring differences in these dimensions across cultures, without understanding fully the implications and possible limitations thereof" (Tung and Verbeke, 2010).

Central to all CCM research endeavours has been the espousal of values based on an essentialist concept, according to which culture is seen as a relatively stable, homogeneous, internally consistent system of assumptions, values and norms transmitted by socialisation to the next generation (Gertsen and Søderberg, 2000; Holden, 2002: 27-29; 
Søderberg and Holden, 2002). But here's the rub: "this essentialist or functionalist view can be valid if we want to understand the characteristics of a particular cultural system, such as a country or a company, but when as in every day international business practice cultures clash and fuse with each other in myriads of ways, the concept is unhelpful: it is virtually programmed to exaggerate the differences between cultures and to generate criteria to rank them competitively" (Holden, 2002: 28). According to Søderberg (2015, forthcoming), "during the last decade this essentialist understanding of culture as relatively static entities has been heavily disputed by cross-cultural management scholars." This is not before time.

It is the fact that values can be held to explain cultural difference, on the one hand, and underpin cross-cultural comparisons, on the other hand, that has made cross-cultural management as an academic discipline so resistant to any major paradigm shift. One consequence of this situation is that the notion of "management" (i.e., explicitly managerial activity) in cross-cultural management has become markedly subordinate to the preoccupation with culture and associated values (Holden, 2002). In the process cross-cultural management, an organisational activity, has become-in a bizarre semantic sleight of hand restricted to the English language-conflated with, and in effect degraded to, "coping with cultural differences," a largely personal experience. Rather than accept this infelicitous state of affairs, scholars are being urged to probe further the interconnection of culture and management (see Primecz, 2011). It is this interconnection, rather than values in themselves, which should form the core of cross-cultural management. Once that it is accepted, new and fertile approaches to cross-cultural management will emerge.

In short, cross-cultural management research "is in a crisis of its own making" and hence "captive of a paradigmatic hermeticism and trapped by favoured ways of thinking" (Lowe et al., 2007). But it is one thing to share this view, and quite another to propose a robust alternative to CCCM's prevailing silo thinking. At the time of writing, it seems impossible to imagine values not being central to the CCM paradigm. This is not to say that values should be completely rejected and supplanted by some other dominant notion. To my mind it is a question of repositioning CCM on the basis of a new approach or, rather, an old approach: namely, anthropology.

\section{A come-back for anthropology?}

Quite apart from anthropologists regarding the world of business education and research as "of little interest" for reasons my co-author may wish to elaborate upon, perhaps the real reason for anthropology failing to make a significant impact on cross-cultural management (CCM) is due to the influence of Hofstede. It may not be an exaggeration 
to say that Hofstede-that is the say, the lasting impact of his work-has made anthropology seem redundant in the eyes of management scholars and, ironically, those working in the CCM paradigm.

Let me qualify that by saying that anthropology's impact has not been nugatory. It has made a contribution in the management literature in fields such as advertising, consumer behaviour, fashion, and the creative industries, and there is of course no shortage of ethnographic studies of businesses. But it is surely fair to suggest that, overall, anthropology's general impact has been uneven and limited. So, where might anthropology make a mark?

First of all there are specific approaches to research, such as discourse studies and organisational analysis, strongly developed in anthropology, which might benefit us. But more importantly in my view, management scholars in general can surely learn a lot about long-term approaches to empirical research. A vast number of empirical studies that end up in the management literature are based on short-term research programmes. This intellectually unsatisfactory state of affairs is, no doubt, due to the enormous pressures in the management field to get research (or "research") published: it does not make for reflection, and conspires to support management studies' preoccupation with confirmation of pre-existing theory.

My impression is that anthropologists are more open to human idiosyncrasy and, therefore, less conformist than their management counterparts. By that I mean that management researchers have a nasty habit of parcelling human beings-not infrequently inhabitants of countries they have never visited-into pre-set, and hence sacrosanct, frameworks when it comes to explaining their economic and social behaviour. It is a remarkable fact, but almost the entire human race has been subsumed under the Hofstede dimensions. With managers being constantly admonished to "think outside the box," perhaps anthropologists or, more probable, anthropological ways of thinking are their best model.

Now to my conclusion: problematically, for more than 30 years the so-called "Hofstede doctrine" (Minkov and Hofstede, 2011) has been largely uncritically accepted across the board in management studies. In my view this has led to intellectual stagnation across the entire management academy and especially regarding IB and CCM. Before Hofstede published his vastly influential Culture's Consequences in 1980, IB scholars (CCM was not a well-defined academic area at the time) might have turned to anthropology as its natural source of knowledge about culture in its international manifestations. They did not do so; nor did anthropologists realise their value to CCM and other branches of management studies. Either way, there is absolutely no doubt in my mind, though I cannot prove this, that anthropology ceded its legitimacy to Hofstede's concept of culture and international business. The time 
may be ripe for anthropologists to claim back the keys to the kingdom!

\section{References}

Adler, N. J. 1983 "Cross-cultural management research: the ostrich and the trend." Academy of Management Review, 8(2): 226-32.

Ader, N. J. 1986 International dimensions of organizational behaviour. Boston, Mass.: PWS-Kent Publishing Company.

Carson, D. 1967 “Anthropological insights." Excerpt from International Marketing: A comparative systems approach. New York: John Wiley \& Sons, 57 and 73-90. In T. Weinshall (ed.) Culture and management: Selected readings, pp. 239-60. Harmondsworth, UK: Penguin Books, 239260.

Eagleton, T. 2000 The idea of culture. Oxford: Blackwell Publishers. French, R. 2010 Cross-cultural management in work organisations. Chartered Institute of Personnel and Development: London.

Gammeltoft, P., Pradhan, J. P. and A. Goldstein 2010 “Emerging multinationals: home and host country determinants and outcomes." International Journal of Emerging Markets, 5 (3/4): 254-65.

Gertsen, M. and Søderberg, A-M 2000 "Cultural change processes in mergers: a social constructionist perspective." Unpublished manuscript. Copenhagen Business School.

Hall, E. T. 1959 The silent language. New York: Doubleday.

Hall, E. T. 1990 Understanding cultural differences. Yarmouth, ME.: Intercultural Press.

Hofstede, G. 1980 Culture's consequences: International differences in work-related values. Beverly Hills, CA: Sage.

Hofstede, G. 2006 "What did GLOBE really measure? Researchers' minds versus respondents' minds." Journal of International Business Studies, 37, 882-896.

Holden, N. J. 2002 Cross-cultural management: a knowledge management perspective. Harlow, UK: Financial Times/Prentice Hall.

House, R., Hanges, P., Ruiz-Quintilla, S., Dorfman, P., Javidan, M., Dickson, M. and V. Gupta 1999 "Cultural influences on leadership and organizations: Project GLOBE." In W. Mobley, M, Gessner and V. Arnold (eds.), Advances in global leadership. Stamford, CT.: JAI Press.

House, R., Javidan, M., Dorfman, P. and V. Gupta 2004 Culture, leadership and organizations: The GLOBE study of 62 societies. Thousand Oaks, CA: Sage. 
Kearney, C. 2012 "Emerging markets research: trends, issues and future directions." Emerging Markets Review, 13: 159-82.

Lowe, S., Moore, F. and A. N. Carr 2007 "Paradigmapping studies of culture and organisation." International Journal of Cross Cultural Management, 7(2): 237-51.

Michailova, S. 2011 "Contextualizing in international business research: why do we need more of it and how can we be better at it?" Scandinavian Journal of Management, 27(1): 129-39.

Minkov, M. and G. Hofstede 2011 "The evolution of Hofstede's doctrine." Cross cultural management, 18 (1): 10-20.

Primecz,, H., Romani, L. and S. Sackmann 2011 Cross-cultural management in practice: Culture and negotiated meanings. Cheltenham, UK: Edward Elgar.

Richman, B. M. 1965 “Significance of cultural variables'. Academy of Management Journal, 8 (4): 292-308. In T. Weinshall (ed.) Culture and management: Selected readings, pp. 15-38. Harmondsworth, UK: Penguin Books, 15-38.

Roberts, K. H. 1975 "On looking at an elephant: an evaluation of crosscultural research related to organizations." In T. Weinshall (ed.) Culture and management: Selected readings, pp. 56-104. Harmondsworth, UK: Penguin Books.

Schwartz, S. 1999 "A theory of cultural values and some implications for work." Applied psychology: An international Review, 48(1): 23-47.

Søderberg, A-M. 2015 (forthcoming) "Indian boundary spanners in cross-cultural and inter-organisational team work: an account from a global software development project." Routledge Companion to CrossCultural Management. London: Routledge.

Søderberg, A-M. and N. J. Holden 2002. "Rethinking cross-cultural management in a globalising business world." International Journal of Cross Cultural Management, 2(1): 103-21.

Tsui, A. S., Nifadkar, S. S., and A. Y. Ou 2007 "Cross-national, crosscultural organisational behavior research: advances, gaps, and recommendations." Journal of Management, 33: 426-78.

Tung, R. and A. Verbeke 2010 "Beyond Hofstede and GLOBE: improving the quality of cross-cultural research." Journal of International Business Studies, 41: 1259-74.

Webber, R. A. 1975 “Convergence or divergence.” In T. Weinshall, T. Culture and management: Selected readings, pp. 39-55. Harmondsworth, UK: Penguin Books.

Weinshall, T. 1975 Culture and management: Selected readings. Harmondsworth, UK: Penguin Books. 
Williams, R. 1958 Culture and society: 1780-1950. London: Chatto and Windus.

Williams, R. 1976 Keywords: A vocabulary of culture and society. London: Collins.

Williams, R. 1981 Culture. Glasgow: Collins.

Ybema, S. and P. Nyíri 2015 (forthcoming) "The Hofstede factor: the consequences of Culture's consequences." Routledge Companion to CrossCultural Management. London: Routledge.

Nigel Holden has been a Visiting Research Fellow at the Centre of International Business of Leeds University Business School (UK) since 2011. His main published output has focused on cross-cultural management in the global knowledge economy, translation in international business, global talent management and business history. His work appeared in the 2014 special issue on language in the Journal of International Business Studies, and he is senior consultant editor of the Routledge Companion to Cross-Cultural Management, due to be published in April 2015. He may be reached at N.Holden@lubs.leeds.ac.uk 